\title{
LEXICON
}

\section{ANIMAL TALES CHEROKEE AND SUMBAWA TRADITION: A STUDY ON CHEROKEE AND SUMBAWANESE VALUES REFLECTED IN THREE PAIRS OF STORIES}

\author{
Vivin Nila Rakhmatullah
}

\section{INTISARI}

Amerika Serikat merupakan sebuah Negara yang terbentuk dari banyak macam pendatang dari berbagai jenis kelompok suku yang berasal dari berbagai tempat di dunia. Kebudayaan rakyat mereka memperkaya dan memberikan kontribusi pada sejarah dan pengalaman Amerika. Indonesia juga merupakan sebuah Negara yang terbentuk dari banyak manusia dan terdiri dari berbagai macam kelompok suku yang berasal dari seluruh daerah kepulauan Nusantara. Maka dari itu tesis ini mempelajari tentang studi perbandingan cerita binatang Cehrokee, salah satu suku asli Amerika dan Sumbawa, salah satu suku di Indonesia. Tujuan dari penelitian ini adalah untuk menjelaskan persamaan dan perbedaan dalam menyampaikan pesan moral dari tiga pasang cerita, mendalami nilai kebudayaan pada cerita binatang dari Cherokee dan Sumbawa, dan juga untuk menguraikan dan menjelaskan penggambaran karakter pada cerita-cerita tersebut.

Tesis ini menggunakan teori multidisiplin di bawah American Studies yaitu "structuralism" oleh Alan Dundes dan "micro to macro" oleh Leo Marx. Dengan menggunakan penelitian kualitatif, dinyatakan bahwa produk budaya (microcosm) yaitu folktales dalam bentuk cerita binatang merupakan cerminan dari kehiupan empiris (kenyataan) dari masyarakat yang memberikan makna pada cerita tersebut. Cerita-cerita binatang ini cerminan kenyataan dari masyarakat Cherokee dan Sumbawa.

Cerita binatang dari Cherokee yaitu How The Terrapin Beat The Rabbit, The Rabbit and The Possum Seek A Wife, dan How The Deer Got His Horns. Sedangkan cerita binatang dari Sumbawa yaitu The Tales of The Monkey, The Turtle and The Snail, The Tales of The Monkey And The Flamingo dan The Cocky Monkey (Sruduk Team). Cerita binatang pada kedua suku menggunakan karakter binatang untuk mewakili manusia, karakteristikkarakteristiknya, nilai moral dan nilai budaya. Karakter inti pada kebanyakan cerita hewan berbeda; Cherokee menggunakan karakter Kelinci (Rabbit), sedangkan Sumbawa menggunakan karakter Monyet. Cerita binatang Cherokee dan Sumbawa hidup dan dijiwai dengan kekuatan dalam membangun identitas dan komunitas.

Kata kunci: studi perbandingan, folklore, cerita binatang, nilai moral, nilai budaya 


\begin{abstract}
United States is a nation that composite of many peoples and consists of various ethnic groups whose origin came from many different parts of the world. Their folklores enrich and contribute the American experience. Indonesia is also a nation that composite of many peoples and consists of various ethnic groups whose origin lives in Indonesian archipelago. Therefore this thesis carries out a comparative study of animal tales of Cherokee, one of Native American tribes and Sumbawa, an Indonesia tribe. The objectives of the study are to explain the similarities and the differences in delivering moral values between the three pairs of tales, to explore the cultural values in Cherokee and Sumbawa animal folktales, and to elucidate the representation of the characters in those animal folktales.

This research employs multidisciplinary theories under American Studies, they are "structuralism" by Alan Dundes and "micro to macro" by Leo Marx. By conducting qualitative research, it is acknowledged that the cultural product (microcosm) that is folktales in form of animal tales is a reflection of the empirical life (realities) of the society that gives birth to it (microcosm). These three pairs of animal tales reflected the realities of Cherokee and Sumbawa society.

The animal tales of Cherokee are How The Terrapin Beat The Rabbit, The Rabbit and The Possum Seek A Wife, and How The Deer Got His Horns. While the animal tales of Sumbawa are: The Tales of The Monkey, The Turtle and The Snail, The Tales of The Monkey And The Flamingo and The Cocky Monkey (Sruduk Team). Animal tales in both tribes are using animal characters to represent human being, their characteristics, moral and cultural values. Their main characters in most of animal tales are different; Cherokee is represented by the character of Rabbit, whereas Sumbawa is represented by the character of Monkey. The animal tales of Cherokee and Sumbawa is very much alive and imbued with power to create identity and community.
\end{abstract}

Keywords: comparative study, folklore, animal tales, moral values, cultural values.

\section{INTRODUCTION}

According to Alan Dundes, the term "Folk" means a group of people who have the same physical characteristics, social, and culture traits (Dundes). Therefore it can be divided into social and cultural groups. In the context of animal tales How The Terrapin Beat The Rabbit, The Rabbit and The Possum Seek A Wife, and How The Deer Got His Horns and The Tale of The Monkey, The Turtle and The Snail, The Tale of The Flamingo And The Monkey and The Sruduk Team it is proven that to some extent, the Cherokee Native American Folk and Sumbawanese Indonesian Folk have a similarity in their view although they have different social and cultural background. According to Danandjaja, the term "lore" is a part of culture, inherited from generations to generations orally or through an example with sign or mnemonic device (Danandjaja 2-1). The "lore" studied in this research is limited on the form of animal tales.

The types of folklore is based on three modes of existence: verbal, non-verbal and partially verbal (Brunvand 3-2). Partiallyverbal folklore includes popular belief and superstition, folk games, folk drama, folk custom, folk festival, and folk dances. Non Verbal folklore includes both traditional materials of folk architecture, arts, crafts, costumes, and food. Verbal folklore includes folk speech, proverb, and 
proverbial saying, while traditional questions are folk riddles. Next are folk rhymes and other traditional poetry, then folk narrative of all kind, and folk song.

Folktales are the short stories of oral literature and it is a part of verbal folklore. Folktales are traditional prose narratives that are strictly fictional and told primarily for entertainment, although they may also illustrate a truth or point of moral (Brunvand 103). Those are stories of magical events and fantastic wonders that are transmitted orally for entertainment and illustrate truth or moral values.

Comparative study of folklore is the study in comparing two, or more, objects of folklore. This thesis is going to examine-compare and contrast-three pairs of animal tales of different cultural, historical, and geographical backgrounds. The sampled tales are the Cherokees' animal tales How The Terrapin Beat The Rabbit, The Rabbit and The Possum Seek A Wife, and How The Deer Got His Horns and the Sumbawanese's The tale of The Mouse-deer and The Snail, The Tale of The Monkey and The Terrapin, and The Sruduk Team. Those three pairs of animal tales are chosen as the representation of Western and Eastern tales to demonstrate the variety of world folklore.

The Sumbawanese animal tales, The tale of The Mouse-deer and The Snail, The Tale of The Monkey and The Terrapin, and The Sruduk Team taught a very basic lesson of life. Indonesian fables usually teaches moral values for children and those moral values derive from the initial cultural background of Indonesia as a nation once consists of kingdoms. In the case of oral tradition, Indonesians, especially rhea Sumbawanese, have a powerful oral tradition, just as powerful as the Native Americans.

Moreover, Dundes stated that folklore is "something alive and dynamic" rather than "dead and static". It is not something relegated to primitivized othershistorically and socially-but rather a behavioral pattern that everyone exhibits
(Bronner 1). Apart from the differences in cultural and geographical backgrounds of the tales sampled in this thesis meet the requirements to be examined in a comparative study of folklore. Therefore, the writer prefers to look in American and Indonesian animal folktales for the answers to the following questions: what is beyond those folktales; what is the function of tables in its society; and are those animal tales still exist in the daily life of both tribal groups?

As afore-mentioned, the Cherokees of Native Americans and the Sumbawanese of Indonesian are presumed to have some similarities in their views of life, albeit the differences in their social, historical and cultural backgrounds. From this point of view, this thesis explores the sampled Cherokees' and Sumbawanese animal tales, looking for similarities and differences, by means of a comparative analysis. Hence, the problems come out as follows: How the Cherokee and Sumbawanese convey their cultural values in their folktales? What are the characters represented in those different animal tales? How is it represented? What are the differences and similarities of the animal tales in delivering moral values?

The thesis is a study on the American Cherokees and Indonesian Sumbawanese's animal folktales. The samples include How The Terrapin Beat the Rabbit (Cherokee), The Tale of The Monkey, The Turtle and The Snail (Sumbawa), The Rabbit and The Possum Seek A Wife (Cherokee), The Tale of The Monkey and The Terrapin (Sumbawa), How The Deer Got His Horns (Cherokee) and The Sruduk Team (Sumbawa). This study focuses on the comparison of the cultural aspects, including the analysis of similarities and differences between these animal folktales, moral values of the tales and their functions in folk life.

This thesis employs a library research method in order to collect the appropriate data needed in analyzing the topic. The data are collected from various sources, 
written materials, on-line articles, and websites. The primary sources are the three pairs of Sumbawanese and Cherokee animal tales which are selected based on the available written version. These written tales are collected from the storytellers then printed in books form. Second, the data is analyzed individually by using the theories of American Studies and folklore to understand the significance of the animal tales that represent its cultures.

The theoretical approaches used are "structuralism" by Alan Dundes and the American Studies approach theory used is the "micro to macro" by Leo Marx. He said that from a small object or artifact we can grasp the big picture (Marx 31). The 'micro' work is the representation of the 'macro' universe. In this perspective, this study sees cultural product (microcosm), folktales, in this case- as a reflection of the empirical life (realities) of the society that gives birth to it (macrocosm). The reflection is represented by the animal characters and in delivering values in folk life.

The next is the "structuralism" theory by Alan Dundes who is unified the "syntagmatic" theory by Vladimir Propp and "paradigmatic" theory by Claude Levi-Strauss. Dundes linked dualism (particularly the importance of "double meaning") in psychoanalysis with the binary basis of structuralism. The pivotal structuralist approaches of Vladimir Propp (syntagmatic, relating to a sequential pattern set of contrasting relations) and while often set in opposition to one another in surveys of structuralist approaches, are unified by Dundes to reveal mental processes underlying the structural patterns of fantastical expressions (Bronner 5).

The term "syntagmatic" structural analysis is adopted from the notion of syntax in the study of language. Propp's syntagmatic approach has unfortunately dealt with the structure of text alone, just as literally folklorist generally have considered the text in isolation from its social and cultural context. In contrast, the paradigmatic of Levi-Strauss has bravely attempted to relate the paradigm(s) he "finds" in myth to the world at large, that is, to other aspects of culture such as cosmology and world view.

Generally speaking, the syntagmatic approach tends to be both empirical and inductive, am dots resulting analyses can be replicated. In contrast, paradigmatic analyses are speculative and deductive, and they are not easily replicated. Then structuralism is combination of syntagmatic and paradigmatic analyses at work. Structuralism is an analytical necessity, working on an identification that led to an interpretation. This is significant in the analysis of folklore and folktale. These analytical steps are taken in this research to analyze the sampled folktale, based on the sequential pattern of plot functions and a thematic set of contrasting relations.

\section{CULTURAL AND MORAL VALUES OF CHEROKEE AND SUMBAWANESE FOLKLORE: A COMPARATIVE STUDY}

\section{Characters Representation}

In the previous chapter, folklore and its parts are defined, and it is mentioned that animal tales is one of the verbal folklore, in which animals, plants and other non-human characters are given the qualities of human to illustrate the lesson or moral values to the audience. In these animal tales of the Cherokees and the Sumbawanese, animals are the only characters to exist.

Native Americans believe in the Great Spirit who has power over all things including animals, trees, stones, and clouds. This Great Spirit controls animals and other elements of the universe. Animals are also important in the life and beliefs of Native Americans. They generally do not consider themselves superior to animals, but believe in animals' 
role in the world as a resource of peoplemeat, skins, or bone for tools. In fact, in Native Americans' 'religions', animals play an important part in the creation of people, and usually have human traits such as speech, or virtues such as bravery or generosity (Garrett and Garrett 14). Whether system in the individual tribe may have, it is deeply rooted in the natural world. Animals, plants, rivers, lakes, mountains and springs are all incorporated into a system of belief that can be called Sacred Geography.

The Supernatural is one of character representations in Indian folktales.

"The supernatural Indian stories are religious experiences that include taboos, rituals, and magics. Natural elements are often personified during the course of a storyline. Mountains, rocks, and rivers may be given human characteristics and feelings, while humans may be turned into fish, stars, or mountains. Just as quickly, these elements may return to their former states. Some characters are permanently assigned natural forms. For example, troublemakers may become mountain peaks as lessons for future rascals. Legends also set human lovers as stars in the sky, destined to chase each other for eternity. Indian tales are filled with an interweaving of supernatural and natural elements." (Markowitz and Barrett 512)

Next, characters may be represented as human. Carole A. Barret states that:

"Human creation myths seek to answer mysteries about the human condition. Human are generally created from supernatural beings, from natural elements, or from animals. In most tales, animals and plants precede the creation of humans." (Markowitz and Barrett 516)

As afore-mentioned, in most tales, animals and plants are considered even more important than human. In the Cherokees' animal tales, the characters are represented as animals. Human generally created form animals as Barret said. The animal characters are used to personify human being in a story. The characters that represent human being are usually the important animals in the Cherokees' belief system.

On the other hand, the Sumbawanese also use animal characters to personify human being in a story and it is similar to the Cherokees. The difference is that the Cherokees believes that human are generally created from supernatural beings, from natural elements, or from animals, whereas the Sumbawanese convince that human is God's creature, created from natural elements of soil, not from animals. The use of animal characters in storytelling is to make it simpler and easier for people in transmitting and understanding the stories. A certain animal represents a certain symbol; different symbols represent different purposes in the stories. Ernest Jones via Dundes states that: "...Symbol always represents a concrete idea, never a general or abstract one." (Dundes 96).

A concrete idea in the tales which is never a general or abstract one implies the values in the tales. Symbols that represented by the animal characters is analyzed in this chapter to seek the concrete meanings and the underlying values of the stories. Again, Ernest Jones explain that:

"The simple fact that these animals, in spite of their frequently objectionable behavior, surprise us by displaying peculiarly human characteristics should provide that a hint to the real meaning. This is no more and no less than that they 
represent particular human beings, most often the parents, especially the father, less often brothers or sisters or children" (Dundes 100-99).

Character, is one of the important elements in the story. The use of different characters in these tales is related to the cultural values in each society where the tales came from. The characters have a special meaning in cultural and moral values of its society. In those animal tales, all of characters are animals representing human beings and the underlying moral and cultural values. An animal character may have similar or different representations in various area or tribes, depending on the values of its society it represents or symbolizes.

Finally, animals function as symbols throughout American culture, from the patriotic image of the bald eagle to the animals employed as mascots for sports teams. Whether used as symbols of human characters or for their own attributes, animals also appear throughout American folk narratives (Watts 17). In representing human beings, animals are needed as the media in spite of human itself. Animals have many characteristics and qualities that are similar to those in human being, make them fit for use as media of representing humans.

The animals in the animal tales or fables, shares many attribute or abilities of human counterparts like what Linda S.Watts stated above. These animals have some similarities with human's characteristics. Somehow these similarities are used in representing the values of a story. Then the animals featured in the animal tales of the Cherokees and the Sumbawanese may be selected for their characteristics, such as characters in the three pairs of animal tales of the two tribes as sampled in this study. In every animal tales, there are some main and additional or supporting characters that build and strengthen the story.

\subsection{Main Characters}

"Every story-every myth-has a 'pragmatic characters'. Every myth serves some purpose or end" (Weaver 17). For the Cherokees, the pragmatic character or the main characters in their animal tales is Rabbit, whereas for the Sumbawanese, the pragmatic character in their animal tales is Monkey.

a. Rabbit

In Cherokee's animal tales, the main characters in most of the animal tales are Rabbit. Rabbit (Jisdu, Tsisdu, Chisdu, Jistu, Tsistu, etc.) is the trickster figure in the folklore of the Cherokees and other Southeastern tribes. His Cherokee name is pronounced similar to jeesedoo (www.native-languages.org).

Rabbit plays a prominent role in the Cherokees' myths. It was always a trickster and deceiver, usually malicious and often beaten at his own game, and by those he intended to victimize. The Cherokees' legends are full of rabbit stories. "The Rabbit goes Duck Hunting," "How the Rabbit Stole the Otter's Coat," "Why the Possum's Tail is Bare," "How the Wildcat Caught the Gobbler," are among others (Mooney 270). The Cherokees' story 'How the Terrapin Beat the Rabbit" taught a very basic lesson of life. That lesson was repeated by the Cherokees' Chief, John Ross, in a letter to his son in 1865. Ross wrote that in the long run, it is the slow and steady pull that accomplishes the most in life. (www.telliquah.com)

\section{b. Monkey}

Monkey (Ne Bote/Nde Bote) is the trickster figure in the folklore of the Sumbawanese. In their animal tales, monkey is a main character in many tutir. The Sumbawanese use the character of Monkey to symbolize smartness, brilliancy, fun, 
agility, but also cunningness as of the Rabbit of the Cherokees. This character is the most appearing characters in the animal tales of Sumbawa. His act, words and attitude represent the dualism in human characters, good, and bad sides.

\subsection{Supporting Characters}

The supporting characters in Cherokee and Sumbawa animal tales are Turtle (Terrapin), Snail, Pig, Fly, Flamingo, Mouse-deer (and Deer of Cherokee), Crocodile, and Fox.

\section{Functions of Animal Tales in the Cherokees' and Sumbawanese Culture}

One of the functions of folklore is to convey values. The Cherokees and the Sumbawanese convey their cultural values in their animal tales that are easily learned, remembered and understood. As a part of folklore, animal tales' functions are as follows:

\subsection{Animal Tales as a matter for Education}

A Sumbawanese storyteller began his betutir (storytelling activity) by saying "Adamo sakowa-kowa deta-e tuter...", meaning "there was once a story of..." or "This is supposedly the story ... (then the storyteller mention the title of the story)". Such kind of sentences is usually recited as an introduction to the animal tales to be told. "Si sakowa-kowa" is the subject of the animal tales and "tuter" is the object of the tales.

On the other hand, discussing about the Cherokee storytellers, Scheer writes in his introduction to Animal Tales of Cherokee:

"Instead of beginning, 'Once upon a time,' the Cherokee storytellers began their tales by saying, 'This is what the old men told me when I was a boy.' The old men were the keepers of tribal traditions, but they were not historians." (Scheer 9)

The quotation above shows that the elder of the tribes is responsible for transmitting the tales which is mean to deliver the moral values to the next generation. That quotation also proves the continuity of the oral storytelling tradition in the Cherokees' culture.

For the Cherokees and Sumbawanese, animal tales serve as one among many media to educate younger generations. The moral values they teach are delivered by means of those animal tales, without any direct reference to real human beings. The tales teach younger generations how to do good things and avoid doing bad things and to accomplish the duty of preserving their people's own local wisdoms and culture, all by means of oral, direct storytelling. Linda J. Meyers, a Native American author describes that "oral storytelling gives importance to the elders in a tribe, for they are respected for their own wisdom. They are the transmitters of traditions and history. They are the transmitters of traditions and history. Through their art, they preserve culture" (Barrett and Markowitz 519).

\subsection{Animal Tales As a matter of Entertainment}

Just like any other tale or story in all culture, all of the animal tales in the Cherokees and the Sumbawanese have a function of entertaining. The tales How the Terrapin Beat the Rabbit (Cherokee), The Tale of the Monkey, The Turtle and the Snail (Sumbawa), The Rabbit and The Possum Seek A Wife (Cherokee), The Tale of the Flamingo and the Monkey (Sumbawa), How the Deer Got His Horns (Cherokee) and The Sruduk Team (The Cocky Monkey) (Sumbawa) are entertaining to either tribe. They serve this purpose by means of the narrative itself, stories about animals. 


\section{The Differences and Similarities of the Animal Tales in the Cherokee and Sumbawanese Cultures in Delivering Moral Values}

The moral values in the three pairs of animal tales of both cultures are varied; some are similar to one another, and some are different from each other. Each pair of animal tales delivers special moral and cultural values implied in the tales.

\subsection{Competition}

The shared theme of the three pairs of animal tales sampled in this study is competition. All of the tales implied the competition between the characters. The competitions are of different type: in the first pair, How the Terrapin Beat the Rabbit and The Tale of The Monkey, The Turtle and The Snail, the competition is represented as a sprint race. In the second pair, The Rabbit and The Possum Seek A Wife and The Tale of The Flamingo and The Monkey, the characters are competing against each other for a betterment of their life. The characters in the tale The Rabbit and The Possum Seek A Wife are competing in seeking a wife, whereas The Tale of The Flamingo and The Monkey in finding a better place to live. In the last pair, How The Deer Got His Horns and The Sruduk Team (The Cocky Monkey), the animal characters compete each other in a tournament. The characters of How The Deer Got His Horns e.i. Rabbit and the Deer, are competing in getting a horn in a contest, whereas the characters in The Sruduk Team (The Cocky Monkey) are rivals against each other in various competitions in a tournament.

Both the Cherokees and the Sumbawanese believe that, in life, competition is unavoidable; it always exists anytime and anywhere, whether they like it or not. The most important thing is the way one responds to any competition: one's response or reaction to it determines one's fate in the future. If one acts bad or untrustworthy to others then they will surely receive punishment in the future. The moral tells people that in real life one should be honest, humble, patient, yet be smart, and must not do any harm to others. By so doing and behaving can one achieve betterment in one's life and live a better life.

\subsection{The Oppressed Defeats Oppressor}

In terms of the moral values, the pair of tales How the Terrapin Beat the Rabbit and The Tale of The Monkey, The Turtle and The Snail contains the value of 'the oppressed defeat the oppressor'. The oppressed characters in the tales are the Terrapin and the Turtle. The Terrapin in the Cherokees' tale is oppressed by the oppressor that is the Rabbit, whereas in Sumbawanese tale The Tale of The Monkey, The Turtle and The Snail, there is a part that shows the Monkey oppressed the Turtle:

"To pick the fruit, the monkey offered his help. He offered himself to climb the tree because the turtle couldn't climb. They agreed to share the fruit equally. Them the monkey climbed the tree. Of course, he was the best animal in climbing. He tried several fruit. How delicious the fruit was! The turtle begged, 'Please, give me some of the fruit,' said the Turtle. 'Wait a while. I just taste the fruit. I am searching for a good one,' said the Monkey. In fact, the peel of banana kept going down. Because of hunger, the turtle ate the peel. 'Spread your blanket so I can throw the banana for you' said the Monkey. How happy The Turtle so he spread his blanket. In fact, the Monkey didn't throw the banana but his feces."

The powerful Monkey uses his ability in climbing to deceive the weak Turtle who cannot climb, but in the end the oppressed Turtle can defeat his oppressor. 


\subsection{The Smart Defeats Arrogant}

In the Cherokees' animal tale How The Terrapin Beat The Rabbit, the Rabbit is represented as arrogant and boastful because it believed that it is the only great runner. Before the race, Rabbit felt so sore of winning the race and said to the Terrapin:

"You know you can't run. You can never win the race. So I will give you a head start. You may start at the top of the first ridge. Then you'll have only three to cross, while I go over four." (Scheer 37)

Rabbit is known as a great runner but its arrogance and boastfulness cost it a lost in the race. It was defeated by the smart trick of the slow Terrapin. The tale tells a moral value that arrogance cannot do any good to anyone and can never lead anyone to a better life.

In the Sumbawanese animal tale The Tales of The Monkey, The Turtle, and The Snail, the Monkey is a representation of the arrogant character. It is punished by the Snail because the Monkey deceived the Turtle. The punishment is a race along the seashore.

"The monkey smiled when knew the game. He said in heart how could the snail beaten the Monkey. The monkey speak arrogantly; 'Well, when it will begin?'."

The Monkey lost the race, because the slowest yet smart Snail beats it. The Monkey dies after running for miles in the race. It could not breathe after eating too much bananas, which are actually belong to the Turtle. Its arrogance led him to death. The moral value tells the audience never to be greedy and arrogant. Bad characters will only lead one into an unlucky fate.

\subsection{Every Actions Determine the Future}

In all of the sampled animal tales, every bad character receives its punishment in the end. But there is a difference in the way the bad characters receive their punishment for being so. In the Cherokees' tales, the bad characters are punished for their mistake, even if the good characters never have the intention to punish them or take them any revenge; natural karma seems to rule that every bad deed deserves punishment in one way or another.

In How The Terrapin Beat the Rabbit; The Rabbit and The Possum Seek A Wife; and How The Deer Got His Horns, the bad character, Rabbit, receives its punishment for being bad in the form of misery. The ending of the story shows that its misery is due to what it has done before to others. Natural karma punishes it when other characters have no intention to take any revenge against the hare. In the end of the story of How The Terrapin Beat The Rabbit;

"The Rabbit could not make another jump. He fell over on the ground, crying, 'Mi! mi! mi! mi!' as the Rabbit has done ever since when he is too tired to run anymore." (Scheer 41)

In the animal tales of the Sumbawanese, on the other hand, each bad character receives punishment in accordance to, or even worse than, what it has done to others. The bad character gets punished by its victim(s), the friend(s) of the victim(s), or by some other characters.

In The Tale of Monkey, the Turtle, and the Snail, The Tale of the Monkey and the Flamingo, and The Sruduk Team (The Cocky Monkey), the bad character is represented by the Monkey, who receives punishment from its friends in several different ways. In The Tale of The Monkey, The Turtle and The Snail, the Monkey is punished by the Snail who challenges the 
Monkey to race along the seashore after the great climber ate the Turtle's bananas. The story ends with the death of the Monkey.

In The Tale of The Monkey and The Flamingo, the Monkey plucked up the Flamingo's feathers. The Flamingo punishes the Monkey by tricking the latter into death after their clay boat is washed away by water and sinks.

"Finally, the monkeys realized what the Flamingo sang. And they said: Don't do that, Flamingo, what will happen to us if this boat sinks?' Right away, the boat which was made of clay was washed away by the water and indeed sank. The Flamingo flew and left the sinking boat and the monkeys dying alone. Most of the monkeys died, except two of them. They stayed alive but crippled and blind, but they gave births to many monkeys which up to the present day have Sumbawa as their home."

\subsection{Dualistic Character of Human Being}

All of the sampled stories imply the moral value of human dualistic character, that there is a good and simultaneously evil character inherent in everyone's character. No bad character is truly bad, and no good is totally good. There is always a natural equilibrium between good and evil in every man.

The Sumbawanese animal tale The Sruduk Team (The Cocky Monkey), for example, portrays the good will of the Monkey, when it helps its friends when they need a help. Some other events in the tale shows that the Monkey has a good will. One day, the Monkey helps the Crocodile:

"One time, Monkey (Ne Bote) walked around in the Valley of Jaran Pusang Mountain. When it was going to cross the river, it heard a scream for help. 'Monkey (Ne Bote) help me from this root. I have been trapped here for a week. In the future, if you need any help, I will help you. When you need it, just clap your hands three time while shouting kicak..kicak..kicak.. Then immediately I will be there.' Skillfully, Ne Bote help get Ne Balo rid of the roots. 'Thank you' said The Crocodile (Ne Balo).”

In one other time the Monkey helps the Fly.
"Before The Crocodile (Ne Balo) left the river, there was a yell abpve the water. 'Monkey (Ne Bote), help me. I am flushed away'. Apparently The Fly (Ne Lalat) was floating in the water. 'When you have trouble, I will help you. But save me first.' Thoroughly, The Monkey (Ne Bote) jumped and raised The Fly (Ne Lalat) from the water. 'Thank you', said The Fly (Ne Lalat). 'When you need my help, just clap your hands three time while shouting kicak..kicak..kicak.. Then immediately I will be there."

Still, in the third time, The Monkey helps The Fox:

"Then The Monkey (Ne Bote) continued his walk till midnight. When he as resting under the Boan tree - big tall tree which has many branches as the habitat of The Bee (Aning) - he heard painful voice. It was The Fox (Rase) which was hurt from the bees' attack. 'Why are you hurt?' said The Monkey (Ne Bote). 'I was stung and attacked by Aning because I hugged their nest. I thought it was a sleeping chicken. I have not eaten for days.' Then The Monkey ( $\mathrm{Ne}$ Bote) takes the leaves of Roga Rampis (a kind of specific herbal) and rubbed it to the Fox's 
body. After a while, the pain eased. Gratefully, Rase said 'When you need my help, I will always be ready to help you. Just clap your hands three time while shouting kicak..kicak..kicak.. Then immediately I will be there."

From those events, it is clear that even the antagonist character, The Monkey, has a good character. It helps its friends when they asked for its help. There is always a natural equilibrium between good and evil in every man.

In conclusion, referring to the previous discussion, both the Cherokees' and the Sumbawanese animal tales are laden with moral and cultural values. These values are implied in the dialogues and the deeds of the animal characters, thus the representations serve a didactic purpose as well, not only that of entertainment. By means of these animal tales, moral and cultural messages are delivered in a very subtle yet enjoyable way, from one generation to the next, thus preserving the traditions, cultures, histories, and all other relevant values from by generations.

\section{CONCLUSION}

The comparative analysis in Chapter IV leads to some conclusion, which includes some similarities, it can be concluded that folktales in either tribe's traditions employ animal characters to represent humans and in delivering the relevant moral and cultural messages. Animals are represented as having human attributes and qualities, and they function as symbols, serving certain purpose(s) in the tales and representing a certain meaning, especially human nature.

Both the Cherokees and the Sumbawanese convey their moral and cultural values by means of their animal tales. The tales are enjoyable as a king of entertainment, and their messages are easily learned, remembered and understood. When their people see the animals, or hear about them in the tales, they will easily recall the underlying moral and cultural values of the stories. Moreover, they will be more closely connected to the nature, not only to the animals but also to the settings of the stories.

In terms of moral and cultural values, both the Cherokees and the Sumbawanese believe that, in real life, competition and dualism in human character do exist everywhere. How they react to such competitions and how they manage the inherent dualism of human character will determine their gate in the future. People need to be honest, humble, patient, as well as smart in dealing with their life, and they must not do any harm to their natural, cultural, and social environments. But, there is no such things as 'pure character'; e.i. no people is totally good and no people is totally evil; both present simultaneously in every human being. These two themes are shared cultural and moral values of both tribes discussed.

In dealing with the theme of animal/human natures, there is yet a difference between the Cherokees and the Sumbawanese in representing and defining certain characters. For an example, the Cherokees use rabbit in symbolizing smartness, brilliancy, agileness, and also cunningness. On the other hand, the Sumbawanese use monkey to symbolize the same psychological traits, even if it is also as cunning as the rabbit of the Cherokees. In the Cherokees animal tales, the bad characters receive punishment for his mistakes, even if the good characters never punish them or take revenge on them. On the other side of the issue, in the Sumbawanese animal tales, bad characters always receive a fair, or even worse, punishment for what he had done to others. They get their punishment from their victims, the friend(s) of the victim(s) or by other character. 
The last conclusion is that the animal tales in both the Cherokees and the Sumbawanese cultures are very much alive and imbued with power to create identity and the culture of the community. The identity of either Cherokees or the Sumbawanese is more or less shaped by the elders' thoughts through their oral tradition. The oral tradition of either culture is expected to keep alive and always memorable in the collective mind of its people, so the animal tales will be alive forever in the minds and hearts of the Cherokees and the Sumbawanese.

\section{REFERENCES}

Abrams, M. H. A Glossary of Literary Terms. New York: Holt, Reinhart and Winston, 19891. Print.

Barret, Carole A. and Harvey J. Markowitz. American Indian Culture. Pasadena: Salem Press, Inc, 2004.

Begawan, Hamid. Menyingkap Tabir dan Budaya Tana Samawa. Sumbawa Besar: Dinas Pariwisata Seni dan Budaya Kabupaten Sumbawa, 2003. Print.

Brunvand. Jan, Harold. The Study of American Folklore. New York: W. W. Norton \& Company. Inc, 1968

Brunvand. Jan, Harold. American Folklore: An Encyclopedia, New York \& London: Garland Publishing, Inc. 1996.

Botkin, B. A. A Treasury of American Folklore: Stories, Ballads, And Traditions of The People, New York: Crown Publishers, 1944. Print.

Bronner. J, Simon. The Meaning of Folklore: The Analytical Essays of Alan Dundes, Utah: Utah State University Press, 2007. Print.

Crawford, J. Suzanne and Dennis F. Kelly. American Indian Religious
Traditions, California: ABC-CLIO, Inc., 2005.

Damono. D, Sapardi. Pegangan Penelitian Sastra Bandingan, Jakarta: Departemen Pendidikan Nasional Pusat Bahasa, 2005. Print.

Danandjaja, James. Folklore Indonesia Ilmu Gosip, Dongeng dan lain lain, Jakarta: Grafitipers, 1984. Print.

Dinas Diknas Kabupaten Sumbawa.

Kumpulan Cerita Rakyat Sumbawa: Tutir Tau Samawa. Sumbawa: Tiara Perkasa Sumbawa, 2006. Print.

Dundes, Alan. The Study of Folklore, Englewood Cliffs: Prentice-hall Inc, 1965. Print.

Elliot, Emory. Columbia Literary History of the United States, New York: Columbia University Press, 1988.

Emrich, Duncan. Folklore on the American Land, Toronto: Little, Brown \& Company, 1972.

Green. A, Thomas. The Greenwood Library of American Folktale, Westpost: Greenwood Press, 2006.

Hoxie. E, Frederick. Encyclopedia of North American Indians, New York: Houghton Mifflin Company, 1996.

Kramsch, Claire. Language and Culture. New York: Oxford University Press, 1998. Print.

Garrett, Michael and J. T. Garrett. Native American: Faith in America. New York: Shoreline Publishing Group LLC, 2003.

Kalimati. Sunan, Wahyu. Pilar-pilar Budaya Sumbawa, Mataram: CV. Mahani Persada Offset, 2005. Print.

Manca, Lalu. Sumbawa Pada Masa Lalu, Surabaya: Penerbit Rinta, 1984. Print.

Marx, Leo. The Machine and the Garden: Technology and The Pastoral Ideal 
in America. New York: Oxford Univ. Press, 1981.

Propp, Vladimir. Morphology of the Folk Tale, Bloomington: The American Folklore Society and Indiana University, 1968.

Rasmussen, Kent, R. American Indian Tribes, Pasadena: Salem Press, Inc, 1995.

Scheer. F, George. Cherokee Animal Tales, Oklahoma: Council Oak Books, 1992. Print.

Selden, Raman. A Reader's Guide to Contemporary Literary Theory, Sussex: The Harvester Press, 1985. Print.

Varner. R, Gary. Creatures in the Mist: Little People, Wild Men and Spirit Beings around the World. A Study in Comparative Mythology, New York: Algora Publishing, 2007.

Velie, R. Alan. American Indian Literature. An Anthology, Norman: University of Oklahoma Press, 1991.

Watts. S, Linda. Encyclopedia of American Folklore, New York: Facts on File, Inc, 2007.

Weaver, Jace. Other Words: American Indian Literature, Law, and Culture, Norman: The University of Oklahoma Press, 2001.

Wolfson, Evelyn. Mythology: American Indian Mythology, Berkeley Heights: Enslow Publisher, Inc, 2001.

Zulkarnain, Aries. Karakteristik Kepemimpinan Dalam Adat dan Rappang Tama Samawa, Sumbawa Besar: Lembaga Adat Tana Samawa, 2008. Print.

Zulkarnain, Aries. Tradisi Dan Adat Istiadat Samawa, Yogyakarta: Penerbit Ombak, 2011. Print.
Microsoft ® Encarta ® 2009. (C 19932008 Microsoft Corporation. All rights reserved www.jshappley.weebly.com. Web. 10 Oct. 2011.

www.native-american-market.com. Web. 10 Oct. 2011.

www.telliquah.com. Web. 5 Nov. 2012. www.coretexts.org. Web. 16 July. 2013. www.native-languages.org. Web. 10 Oct. 2011. www.ibiblio.org. Web. 16 July. 2013. www.ceritarakyatnusantara.com. Web. 16 July. 2013. 